DOI:

УДК 622.673 .1

О.В. Панченко, к.т.н., доцент, panchenko.o.v@nmu.one

Д.О. Боднар, студент, bodnar.d.o@nmu.one

Національний технічний університет «Дніпровська політехніка», м. Дніпро

\title{
РОЗРОБКА МАТЕМАТИЧНОЇ МОДЕЛІ НАПРУЖЕНО-ДЕФОРМОВАНОГО СТАНУ БАРАБАНІВ ШАХТНИХ ПІДІЙМАЛЬНИХ МАШИН
}

В роботі вирімена актуальна наукова задача, яка полягає в розробиі математичної моделі залежності напружено-деформованого стану барабана від параметрів підкріплення барабанів шахтних підіймальних машин. Метою роботи є розробка науково-обтрунтованих рекомендачій щодо вибору параметрів підкріплюючих елементів барабанів. Отримано залежності напружено-деформованого стану барабана від параметрів підкріплюючих елементів. Рекомендується використовувати отримані закономірності при проектуванні вітчизняних шахтних підіймальних машин з изиліндричним барабаном.

Ключові слова: ииліндричний барабан, шахтна підіймальна машина, підкріплюючі елементи, напруження, конщентратор напружень

In the work an urgent scientific problem has been solved which consists in the development of the mathematical model of the dependence of the stress-strain state of the drum on the parameters of reinforcement of the drums of mine hoisting machines. The aim of the work is to develop scientifically grounded recommendations on the choice of the parameters of reinforcing elements of the drums. The dependences of the stress-strain state of the drum on the parameters of the reinforcing elements are obtained. It is recommended to use the obtained regularities in the design of domestic mine hoisting machines with a cylindrical drum.

Keywords: cylindrical drum, mine hoisting machine, reinforcing elements, stresses, stress concentrator.

\section{Постановка проблеми}

Шахтні підіймальні машини (ШПМ) вітчизняного виробництва, на відміну від зарубіжних, виготовляються з підкріплювальними елементами, що спричиняє високі напруження в конструкції через наявність концентраторів $[1,5]$. Тому, актуальною технічною проблемою $є$ підвищення міцності барабанів при досягненні мінімальної його маси за допомогою методів математичного та комп'ютерного моделювання.

\section{Аналіз останніх досліджень та публікацій}

Традиційні напіваналітичні математичні методи дають осереднену оцінку напруженодеформованого стану (НДС) барабана проектованої конструкції ШПМ і не дозволяють оцінити залежність напружено-деформованого стану барабана від вибору тих чи інших видів підкріплень [1-3]. Отже, необхідно для заданих вихідних даних проєктованої ШПМ перебрати всі можливі варіанти підкріплень барабана за критерієм мінімум маси і максимальної міцності. А після обробки результатів обчислювального експерименту отримати математичні моделі НДС, використовуючи котрі можна визначити необхідні параметри підкріплень.

Таким чином, розробка математичної моделі залежності напружено-деформованого стану барабана від параметрів підкріплення шахтної підіймальної машини — актуальне наукове завдання.

\section{Формулювання мети дослідження}

Метою роботи є розробка науково-обгрунтованих рекомендацій щодо вибору параметрів підкріплюючих елементів барабанів шахтних підйомних машин.

\section{Виклад основного матеріалу}

Сучасні барабани підіймальних машин НКМЗ виготовляють зварними з використанням листового прокату і нарізкою під канат по металевій футеровці. Машини з одним розрізним барабаном виконують 3 двох частин: однієї вузької переставної, що служить для розміщення на 
ній витків тертя і запасних витків каната, а іншої - широкої нерухомо закріпленої на валу. Заклинену частину барабана приварюють до труби жорсткості, яку закріплюють болтами до двох маточин, які посаджені на корінний вал. Ліва маточина посаджена на вал по гарячій посадці. Права заклинена на валу тангенціальними шпонками. Переставну частину барабана встановлюють на правій заклиненій маточини, вона може вільно перекочуватися по ній при вимкненому механізмі перестановки завдяки роликовій опорі, що обертається.

Складений головний вал підіймальної машини ЦР-6Ч3,2 подано на рис. 1 [4]. Тут позначено: 1 - переставний барабан; 2 - заклинений барабан; 3 - підшипникова опора, кінцева; 4 - підшипник проміжний; 5 - механізм перестановки (розчіпний пристрій); 6 - головний вал підіймальної машини; 7 - змащувальна система опор переставного барабана; 8 - нерухома маточина заклиненого барабана; 9 - маточина переставного барабана; 10 - гальмівні диски; 11 - реборди; 12 - муфта.

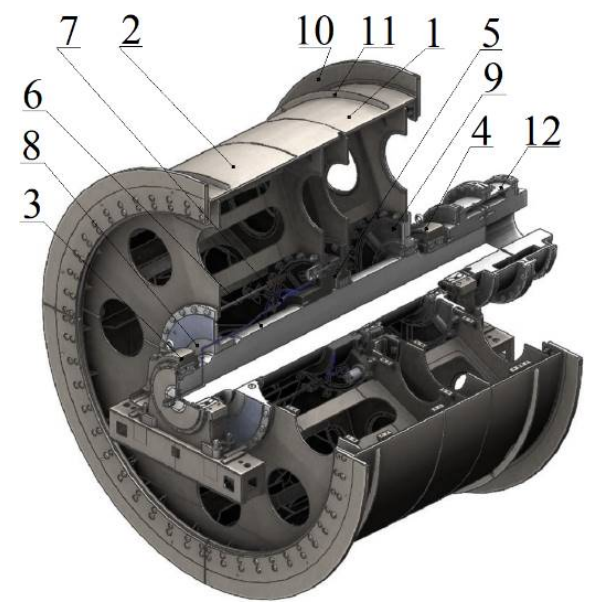

Puc. 1. Складений головний вал підіймальної машини ЦР-6Ч3,2

Навивка будь-якого витка каната призводить до деформації обичайки барабана, внаслідок чого деформуються раніше навиті витки $[5,6]$. При цьому змінюється натяжіння витків каната, яке змінює радіальне навантаження на обечайку барабана. Прийнято, що натяжіння каната в межах кожного витка постійно, при цьому спіральна канавка замінена кільцевою. Це робить можливим вирішувати задачу як вісесиметричну $[7,8]$. Для дослідження впливу цього навантаження на напружено-деформований стан барабана в додатку SolidWorks Simulation за допомогою методу скінченних елементів (МСЕ) необхідно створити тривимірну твердотілу модель $[4,7]$.

Геометричні моделі заклиненої і переставної частин барабана шахтної підіймальної машини ЦР-6Ч3,2 (рис. 2) складаються 3: моделей обичайки 1 з кільцевими канавками; гальмівних полів 2; двох кільцевих реборд і кільцевої циліндричної області для розміщення витків тертя i запасного каната 3 ; лобовин 4. Для дослідження напружено-деформованого стану барабана була створена його параметрична модель, в якій передбачено для збільшення жорсткості барабанів різні види підкріплень. У моделі можна змінювати параметри товщини обичайки і лобовини, розміри шпангоутів, косинок, радіальних ребер жорсткості.

Поставлено завдання: дослідити вплив конструктивних факторів заклиненої частини барабана на їі НДС.

Основним параметром для дослідження є максимальне статичне натяжіння навантаженої вітки каната - яке за технічними вимогами становить не менше 320 кН.

В якості підкріплень в барабані можуть бути ребра, стрингери (поздовжні ребра), шпангоути (кільцеві ребра), косинки. На моделі заклиненої частини барабана при товщині лобовини 
40 мм і відстані між лобовиною і площиною розрізу 5...6 канавок, з максимальним розміром скінченого елемента сітки 20 мм, було проведено розрахунок НДС для підкріплень.

Ділянку заклиненої частини, яка межує з площиною розрізу та з іншого боку обмежена лобовиною, найчастіше підкріплюють косинками. Окрім такого розташування косинок створено підкріплення цієї ділянки шпангоутом, який межує з площиною розрізу. Також взято місце розташування шпангоута симетричне останньому відносно лобовини.

Для збільшення жорсткості обичайки та між отворами лобовини до них приварено ребра з криволінійним переходом.

Для порівняння впливу на НДС барабана підкріплень, що збільшують кільцеву жорсткість обичайки, досліджено вплив підкріплень, які використовують для збільшення поперечної жорсткості обичайки - стрингери. Було запропоновано три їх види: трапецеїдальні з обробкою твірної після зварювання, трапецеїдальні зі зміною кута нахилу твірної, П-подібні.

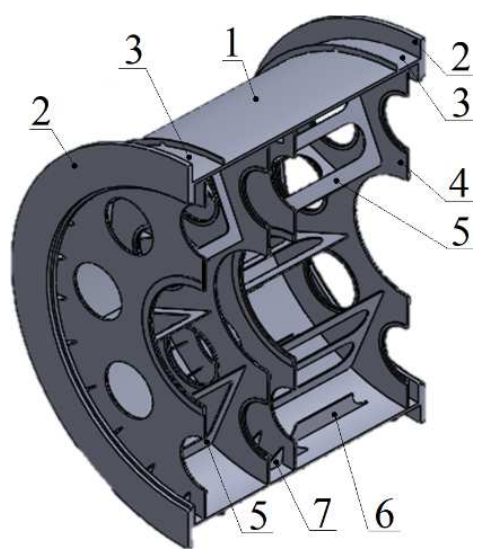

Рис. 2. Параметрическая модель барабана шахтной подъемной машины ЦР-6Ч3,2

Деякі комбінації підкріплень неможливо виконати з конструктивних міркувань. У даній моделі (рис. 2) використовувалися ребра 5 в кількості 6 шт. на кожну лобовину, стрингери 6 у кількості 16 шт. на обичайці між лобовинами, косинки 7 в кількості 40 шт. на ділянці заклиненої частини, яка межує з площиною розрізу і з іншого боку обмежена лобовиною. Розглянуто всі можливі комбінації підкріплень.

У першій частині експерименту незмінними обрані неперервні чинники положення лобовини та іiі товщини. На моделі $1 / 8$ заклиненомої частини барабана при товщині лобовини д $=40$ мм, і відстані між лобовиною і площиною розрізу 5,6 довжини канавки.

Результати обчислювального експерименту оброблялися за допомогою методу найменших квадратів. 3 аналізу результатів обчислень випливає, що найбільш вдалим підкріпленням $€$ шпангоут, приварений до обичайці заклиненому частини, розташований на тій же відстані, що і від лобовини до гальмівного диска. З'ясувалося, що це підкріплення дає найменші максимальні напруження. Однак в оболонці напруження перевищують припустимі значення (155 МПа при пульсуючих навантаженнях $[7,8])$, а також збільшує масу барабана на 400 кг.

Найбільш невигідним за металоємністю є поєднання реберного підкріплення, двох Побразних стрингерів. У порівнянні з барабаном без підкріплень воно збільшує максимальні напруження на $38 \%$. Найбільш небезпечний за напруженнями - це випадок підкріплення стрингером 3 обробкою твірної в будь-якій комбінації з іншими підкріпленнями (збільшує напруження в порівнянні з барабаном без підкріплень на 133-151\%), і дає збільшення маси від 1160 кг.

Випадок без підкріплень 3 точки зору маси найбільш вигідний. Тут максимальні напруження виникають на поверхнях канавок, які знаходяться над з'єднанням обичайки 3 лобовиною близько площині розрізу. Наявність підкріплень має викликати розвантаження обичайки i, в 
наслідок, зміщення максимальних напружень на самому підкріпленні. Шпангоути при малому кроці установки (250-300 мм для даного барабана) не переміщають максимальні напруження, але збільшують жорсткість обичайки і зменшують на ній інтенсивність напружень. На косинках виникають максимальні напруження в місці з'єднання іiі з лобовиною. Для ребер максимальні напруження практично не виникають. При спільному використанні цих підкріплень максимум напружень спостерігаємо на косинках. У порівнянні косинок і П-образних стрингерів, при спільному їх використанні, найбільш небезпечними за напруженнями є косинки, а при двох інших конструкціях стрингерів максимальні напруження виникають саме в них.

У порівнянні ребер і П-образних стрингерів, при спільному їх використанні, найбільш небезпечними за напруженнями виявляються стрингери, але максимальні значення в них найбільш близькі до допустимих.

Отже, в якості реберного підкріплення необхідно вибирати комбінацію ребер і Побразних стрингерів. Однак необхідно провести додаткові дослідження для визначення геометричних розмірів П-образних стрингерів, при яких інтенсивність напружень буде перебувати в допустимих межах.

Внаслідок аналізу встановлено, що значущим параметром, що характеризує напруженодеформований стан проектованого барабана, $\epsilon$ параметр $H$, а його граничні значення знаходяться в діапазоні $0-600$ мм (див. рис. 3).

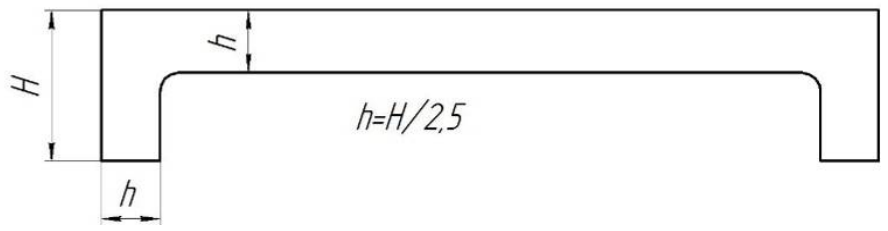

Рис. 3. Параметри П-образного стрингера

Результати дослідження подані в графічному вигляді на рис. 4, з якого видно, що інтенсивність напружень зменшується від 500 МПа до 150 МПа (при допустимих 155 МПа). Також отримано, що при значенні $H=450$ мм напруження досягли свого мінімального значення, i подальше збільшення довжини приводить тільки до збільшення маси.

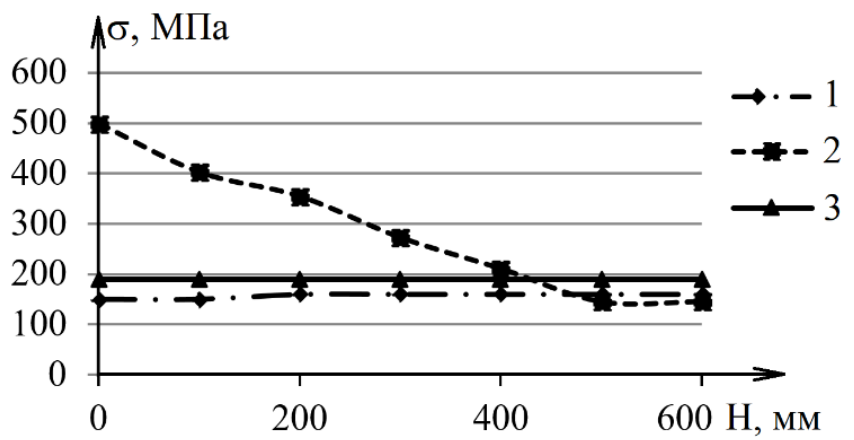

Puc. 4. Графік залежності напруження в барабані від висоти стрингера: 1 -в обичайці; 2 - у стрингері; 3 - допустиме напруження

Математичну модель залежності напружень в барабані від висоти стрингера запишемо у вигляді полінома:

$$
\sigma(H)=k_{1} \cdot H^{3}-k_{2} \cdot H^{2}-k_{3} \cdot H+k_{4} \text {, }
$$

де $\{k\}^{T}=\left\{1,306 \mathrm{MПа} /\right.$ мм $^{3} \quad 10,49 \mathrm{MПа} /$ мм $^{2} \quad 49,51 \mathrm{MПа} /$ мм $\left.551,9 \mathrm{MПа}\right\}$ - визначені методом найменших квадратів. 
Таким чином, параметр $H$ необхідно вибирати зі співвідношення: $H / B \geq 0,17$ (тут $B$ - ширина барабана).

Крім того, виконані дослідження дали можливість виявити оптимальну схему реберного підкріплення. А саме, рекомендується використовувати для заклиненої частини барабана П-образний стрингер в комбінації з ребрами, встановленими між лобовиною і гальмівним диском. Геометричні параметри елементів барабана (обичайки, лобовини, підкріплень) обрані 3 умови мінімум маси й обмеженням у вигляді допустимих напружень, та показані на рис. 5.

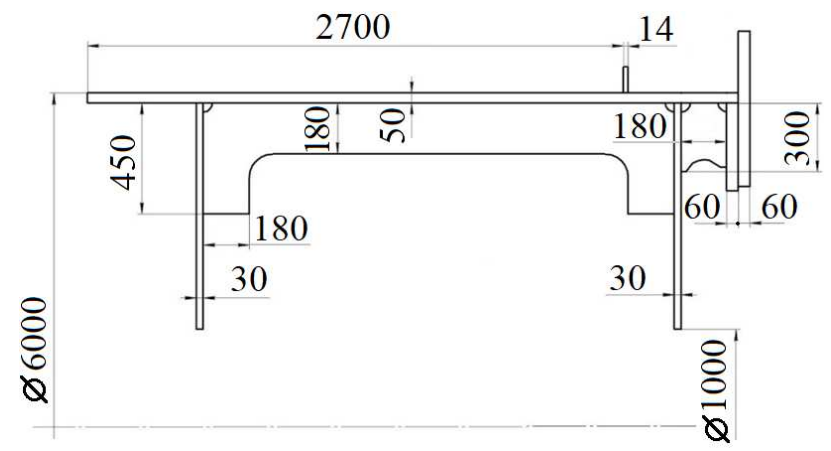

Рис. 5. Геометричні параметри елементів барабана

Виконаний перевірочний розрахунок підтверджує працездатність конструкції. Результати скінчено-елементного аналізу показані на рис. 6. 3 епюри напружень видно, що при вибраних параметрах максимальні значення склали 127 МПа, що нижче гранично допустимого. При цьому, маса конструкції менше на 8\% в порівнянні з вихідною. Крім того, переміщення в обичайці не перевищують 0,7 мм. Отже, конструкція допустима за умовою стійкості та допуску на переміщення.

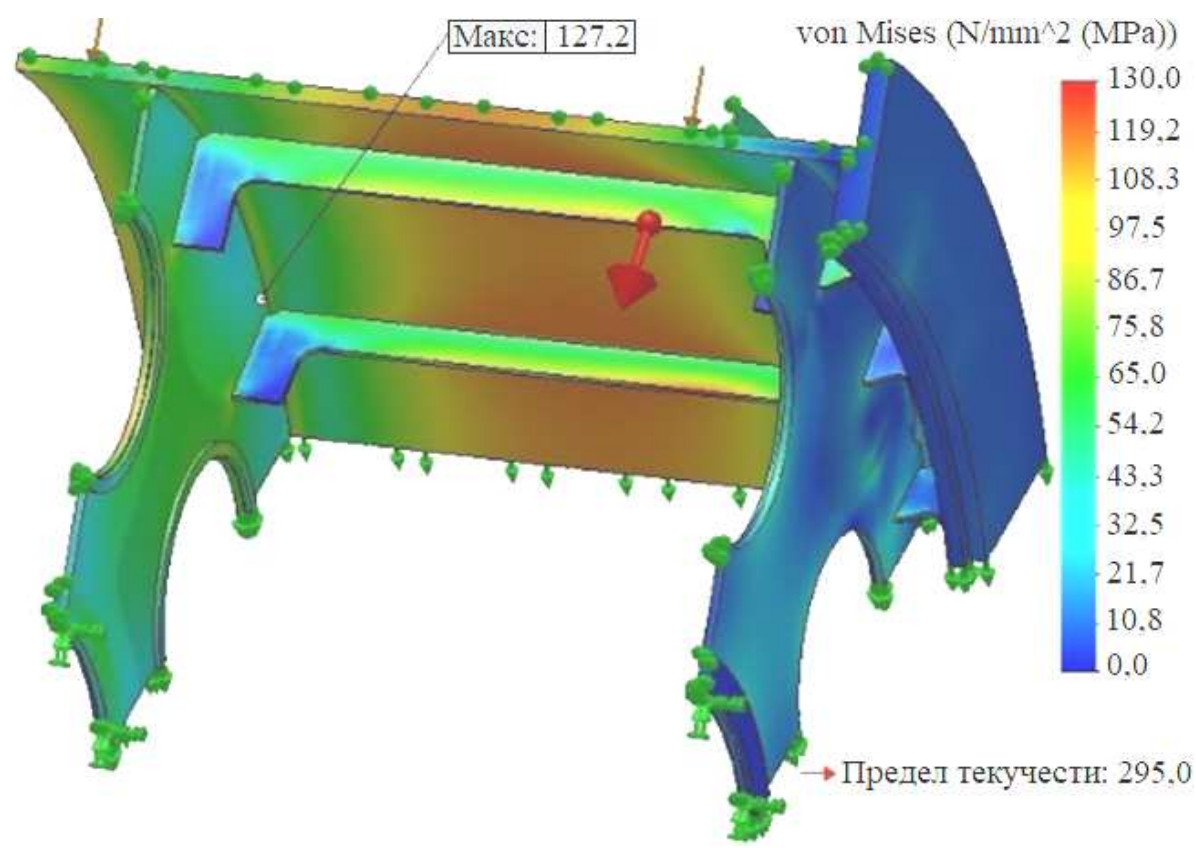

Рис. 6. Дослідження НДС з прийнятими підкріпленнями 


\section{Висновки}

У шахтних підіймальних машинах типу ЦР напружено-деформований стан барабана істотно залежить від обраної схеми реберного підкріплення, а саме:

- конструкція барабана без підкріплень має мінімальну масу, але еквівалентні напруження на поверхнях канавок перевищують допустимі в зоні стику лобовини з обичайкою;

- косинки, які з'єднують лобовину з обичайкою, є концентратором напружень і використовуються в конструкції як страхувальні елементи;

- короткі стрингери, що встановлені на внутрішній поверхні обичайки, практично не збільшують жорсткість барабана, але самі є концентратором напружень; барабана;

- П-образні стрингери, збільшують міцність конструкції, але істотно збільшують масу

- шпангоути практично не збільшують міцність конструкції при недостатній їх кількості;

- рекомендується використовувати для заклиненої частини барабана П-образний стрингер в комбінації з ребром.

У конструкції підіймальної машини ЦР-6Ч3,2 мінімальні напруження в обичайці спроектованого барабана забезпечує комбінація П-образного стрингера і ребра, причому параметр стрингера $H$ необхідно вибирати зі співвідношення $H / B \geq 0,17$.

\section{Список використаної літератури}

1. Zabolotny K., Zhupiev O., Molodchenko A. Analysis of current trends in development of mine hoists design engineering. New Developments in Mining Engineering-2015. Theoretical and Practical Solutions of Mineral Resources Mining. CRC Press/Balkema. P. 175-179.

2. Ilin S. R., Samusia V. I., Ilina I. S., Ilina S. S. Influence of dynamic processes in mine hoists on safety exploitation of shafts with broken geometry. Scientific bulletin of the National Mining University. Dnipro, 2016. № 3. P. 42-47.

3. Zabolotnyi K., Panchenko O., Zhupiiev O., Jamil Sami Haddad. Justification of the algorithm for selecting the parameters of the elastic lining of the drums of mine hoisting machines. Ukrainian School of Mining Engineering - 2019: Materialy E3S Web of Conferences. № 123 (01021). P. 5565. Retrieved from https:// doi.org/10.1051/e3sconf/201912301021.

4. Zabolotnyi K., Panchenko O., Kuts O. Justification of design models of drums of mine winders ЦР. Innovative development of resource-saving technologies and sustainable use of natural resources: Book of Abstracts 3nd International Scientific and Technical Internet Conference. (Petroșani, Romania: UNIVERSITAS Publishing, 26 october, 2020). Petroșani, 2020. P. 224-227.

5. Zabolotnyi K., Panchenko O., Zhupiiev O. Development of the theory of laying a hoisting rope on the drum of a mining hoisting machine. Essays of Mining Science and Practice 2019: Materialy E3S Web of Conferences. № 109 (00120). P. 104 - 118. Retrieved from https://doi.org/10.1051/e3sconf/201910900121.

6. Moskalyova T. V., Polushyna M. V. Cross way of fastening steel ropes to a singledrum mine hoisting plant with the location of pulleys on the same axis. Scientific bulletin of the National Mining University. Dnipro, 2016. № 3. P. 56-62.

7. Zabolotnyi, K.S., Zhupiiev, O.L., Sosnina, Ye. M. (2012). Study of deflected mode of mine winder split drums. Scientific bulletin of the National Mining University. Dnipro, 2012. № 1. P. 82-88.

8. Zabolotny K., Zhupiev O., Molodchenko A. Development of a model of con-tact shoe brake-drum interaction in the context of a mine hoisting machine. Mining of Mineral Deposits. Dnipro, 2017. № 11 (4). P. 38-45. 


\title{
DEVELOPMENT OF A MATHEMATICAL MODEL FOR THE STRESS-STRAIN STATE OF MINE HOISTING MACHINES DRUMS Panchenko O., Bodnar D.
}

\begin{abstract}
In the work an urgent scientific problem has been solved which consists in the development of the mathematical model of the dependence of the stress-strain state of the drum on the parameters of reinforcement of the drums of mine hoisting machines. The aim of the work is to develop scientifically grounded recommendations on the choice of the parameters of reinforcing elements of the drums.

As a result of the performed computational experiment, it is shown that the stress-strain state of the drum depends significantly on the selected rib reinforcement scheme. The design of the drum without reinforcements has a minimum mass, but the equivalent stresses on the surfaces of the grooves exceed the allowable ones in the area of the joint of the front member with the shell. The gussets that connect the front member to the shell are a stress concentrator and are used in the structure as safety elements. Short stringers installed on the inner surface of the shell practically do not increase the stiffness of the drum, but are themselves a stress concentrator. U-shaped stringers increase the strength of a structure, but significantly increase the mass of the drum. Frames practically do not increase the strength of the structure with an insufficient number of them. It is recommended to use a U-shaped stringer in combination with a rib for the jammed part of the drum. In the design of the CR-643.2 hoisting machine, the minimum stresses in the shell of the designed drum are provided by a combination of the U-shaped stringer and rib, and the stringer parameter $H$ must be selected from the ratio $H / B \geq 0.17$. The mathematical model has been obtained that describes the equivalent stresses in the drum depending on the stringer height.
\end{abstract}

\section{References}

[1] Zabolotny, K., Zhupiev, O. \& Molodchenko, A. (2015). Analysis of current trends in development of mine hoists design engineering. New Developments in Mining Engineering-2015. Theoretical and Practical Solutions of Mineral Resources Mining, pp.175-179 [in United Kingdom]

[2] Ilin, S. R., Samusia, V. I., Ilina, I. S., Ilina S. S. (2016). Influence of dynamic processes in mine hoists on safety exploitation of shafts with broken geometry. Scientific bulletin of the National Mining University, 3. 42-47 [in Ukraine]

[3] Zabolotnyi, K., Panchenko, O., Zhupiiev, O. \& Jamil Sami Haddad. (2019). Justification of the algorithm for selecting the parameters of the elastic lining of the drums of mine hoisting machines. Ukrainian School of Mining Engineering - 2019: Materials E3S Web of Conferences. 22 October 2019. Vols. 123 (01021), 55-65. Retrieved from https:// doi.org/10.1051/e3sconf/201912301021 [in Ukraine]

[4] Zabolotnyi, K., Panchenko, O. \& Kuts, O. (2020) Justification of design models of drums of mine winders CR. Innovative development of resource-saving technologies and sustainable use of natural resources: Book of Abstracts 3nd International Scientific and Technical Internet Conference. 26 october $2020 y$. (pp. 224-227). Petroșani: Universitas Publishing [in Romania]

[5] Zabolotnyi, K., Panchenko, O. \& Zhupiiev, O. (2019). Development of the theory of laying a hoisting rope on the drum of a mining hoisting machine. Essays of Mining Science and Practice 2019: Materialy E3S Web of Conferences. 09 July 2019. Vols. 109 (00120), 104 - 118. Retrieved from https://doi.org/10.1051/e3sconf/201910900121 [in Ukraine]

[6] Moskalyova, T. V., Polushyna, M. V. (2015). Cross way of fastening steel ropes to a singledrum mine hoisting plant with the location of pulleys on the same axis. Scientific bulletin of the National Mining University, 3. 56-62 [in Ukraine]

[7] Zabolotnyi, K.S., Zhupiiev, O.L., Sosnina, Ye. M. (2012). Study of deflected mode of mine winder split drums. Scientific bulletin of the National Mining University, 1. 82-88 [in Ukraine]

[8] Zabolotny, K., Zhupiev, O. \& Molodchenko, A. (2017). Development of a model of con-tact shoe brake-drum interaction in the context of a mine hoisting machine. Mining of Mineral Deposits, 11 (4), 38-45 [in Ukraine] 